\title{
LESSONS LEARNED FROM REMOTE EDUCATION
}

\author{
Květoslava Šimková ${ }^{1}$;itka Ramadanová ${ }^{2}$ \\ University of West Bohemia in Pilsen, \\ Institute of Applied Language Studies, English Section, \\ Univerzitní 8, 30100 Plzeň, Czech Republic \\ e-mail: ${ }^{1}$ ksimkov@ujp.zcu.cz; ${ }^{2}$ ramadano@ujp.zcu.cz
}

\begin{abstract}
This article focuses on some aspects of remote education that can be implemented in face-toface classes in order to improve and enhance the teaching/learning process. The authors present the results of the questionnaire survey conducted among the teachers of the Institute of Applied Language Studies of the University of West Bohemia in Pilsen (hereinafter referred to as 'UWB') and also among the students of the Faculty of Economics at the same university in the spring term of 2021, evaluating two semesters of remote education. Having analyzed the results of the questionnaires, the authors of the article aim to share their experience and introduce the best practice that the Business English (hereinafter referred to as 'BE') teachers at the UWB have decided to apply to their future BE courses.
\end{abstract}

\section{Keywords}

Remote education; Business English; Online teaching and learning; Face-to-face classes; Videoconferencing tools; Online applications.

\section{Introduction}

The Covid-19 pandemic has forced all educational institutions in the Czech Republic to switch to remote education virtually from day to day. Both teachers and students went online and did their best to cope with the challenging, unprecedented situation.

What is meant by remote education? We can be sure that there exist numerous definitions. According to one of them, given by Ofsted in [1]:

"Remote education is any learning that happens outside of the classroom, with the teacher not present in the same location as the students."

No doubt there are many advantages as well as disadvantages in teaching and studying online, which are currently being discussed. For obvious reasons, we are interested mainly in the benefits, as these can be exploited for the more fulfilling teaching and learning experience. Online education can foster a more student-centred learning approach, where learners become autonomous, active, and more responsible for the results of their learning. At the same time, the traditional role of the teacher changes as he or she becomes more of the "guide on the side than the sage on the stage" [2], meaning that the teacher adopts a more supporting approach being the facilitator of the learning process rather than the exclusive content expert. As Rai \& Rajeshwari in [3] point out,

"the online learning approach will help promote self-directed learner autonomy with improved scope for customized thought and increased content interaction."

Another advantage of online teaching and learning is the "vast resources of the Internet" [4] that BE students can use. "Everything is open and useful: from the use of online dictionaries 
to videos on a given topic" This is helpful in teaching BE and English for specific purposes, such as tourism, finance, presentations, videoconferencing, etc.

Digital platforms also allow us to save notes in shared documents, such as students' assignments including teacher's comments, study materials, and references to online resources, which makes it easier for students to revise the topics covered in the given term.

The majority of videoconferencing tools enable teachers to practise speaking in a foreign language as well. Gruber in [5] highlights that

"recent developments in technology make a more authentic way of communicating possible than with static video conferencing systems and for the purpose of speaking practice, instructors can allocate learners to breakout rooms and join the breakout rooms themselves."

Alexeeva and Buryakova in [6] see a big potential in blended learning (or hybrid learning), which they consider to be a changeover from face-to-face to distance online learning. They also stress that technology and methodology play an important role in the effectiveness of blended learning.

One of the recommendations of UNESCO for higher education is to implement a hybrid model of teaching and learning processes, drawing on the lessons learned from Covid-19 [7].

It becomes apparent that some aspects of the remote/online education can be applied when going back to physical classrooms.

Thus, the authors of this article decided to survey both the BE teachers and the students of economics enrolled in BE courses in the 2020/2021 academic year to assess what worked well in the online environment in order to identify the elements of remote education that might be retained for the future.

Firstly, the article briefly describes the BE courses offered to students of economics at UWB in Pilsen. It also looks at the challenges that the teachers faced while moving to the online environment. The next part of the article presents the online questionnaire survey completed by the BE teachers and its results. Then, the online survey addressed to the BE students at UWB in Pilsen is described and the results are summarized. Finally, the article compares the results of the two surveys and presents the elements of the remote/online education that $\mathrm{BE}$ teachers have decided to implement in further BE courses.

\section{Business English Courses at the University of West Bohemia in Pilsen}

\subsection{Key Information on Business English Courses}

Business English courses at UWB are offered by the Institute of Applied Language Studies to students of Bachelor and Master study programmes at the Faculty of Economics. Over the years, the courses underwent the process of gradual innovation. The main objective of this effort is to enhance the quality of the students' language skills, so that they could be better competitive on both the Czech and European labour markets. Thus, the courses of Business English from B1 to B2 level according to CEFR went through significant changes in terms of their structure and content.

The courses, both compulsory and optional ones, are intended for full-time, as well as parttime students. The compulsory courses, in other words the core courses of Business English 1-4 are intended mainly for first-year students. The teachers involved in several innovation projects replaced the formerly used teaching materials, i.e., the Profile books 2 and 3 (Oxford University Press), with the book series Business Benchmark Pre-intermediate for the less 
advanced students attending courses AC5B and AC6B and Business Benchmark Upper Intermediate for the more advanced students attending courses $\mathrm{AC} 7 \mathrm{~B}$ and $\mathrm{AC} 8 \mathrm{~B}$. In our opinion, these books, published by Cambridge University Press, provide the teachers and students with relevant material for topic-based courses, covering the grammar structures, vocabulary and skills needed for problem-free communication in the business context.

BE teachers developed weekly plans for the four above-mentioned core courses plus "the package" containing tasks for part-time students. The content of the core BE courses has been unified and is taught by several teachers in parallel. The BE teachers at UWB in Pilsen also use the standardized credit tests to check the students' knowledge at the end of each term.

Apart from the core courses, there are optional courses that students can choose from. Among these are English for Business Communication, English for Tourism, English for Finance and Banking, and Business Culture Studies in English. All the courses have their own Courseware pages, so the key information on the BE courses can be found not only in the information system of the university, the so-called IS/STAG, but also on the Courseware. However, the Courseware has been found insufficient for communicating all the information concerning assignments and supplementary language exercises to the students.

\subsection{Challenges Faced while Moving Online}

There was a choice of 3 platforms/LMS systems, namely Courseware, Moodle, and Google Classroom. Since Google Classroom was used as the main platform for communicating with the students in the spring of 2020 after the first outbreak of Covid-19, all of the BE teachers chose the same platform in the 2020/2021 academic year again, mainly due to its versatility and ease of use.

Needless to say, the BE teachers actively participated in different training sessions organized by UWB or directly by the Institute of Applied Language Studies to master the most common videoconferencing tools, LMS systems, and online applications designed for online teaching and learning. All the teachers were prepared for the different teaching scenarios in the winter semester of 2020/2021. The training sessions ran from the spring of 2020 to June 2021 online, so the $\mathrm{BE}$ teachers received training in the tools they decided to use in their online teaching.

Despite following the same course plan and content, and using Google Classroom as the main platform, the BE teachers could choose how to teach their BE courses, i.e., they could decide on their own which videoconferencing tool and applications they wanted to use in their online classes.

As for the videoconferencing tools used at UWB in Pilsen, the BE teachers had the choice of Google Meet, MS Teams, and ZOOM. They used mainly ZOOM and Google Meet. From the very beginning, ZOOM has become the most popular one, especially thanks to its breakout rooms, allowing teachers to divide students into pairs or small groups for discussions and subsequent presentations.

Language teachers can make use of a variety of online language applications, for example, Wordwall, Quizlet, LearningApps, Mentimenter, Wakelet, Nearpod, etc. Creating exercises in them is easy and the links to such online exercises can be shared with the students for repeated practice directly in Google Classroom.

In summary, the BE teachers have successfully used the online tools, applications and LMS systems mentioned above in their remote teaching, which became clear from the students' responses. What they could not influence was the occasionally unstable Internet connection, which was a trouble for anyone using videoconferencing tools. 


\section{Online Teaching Survey}

At the end of the BE courses, that is at the beginning of May 2021, a questionnaire consisting of sixteen questions was sent to the BE teachers to obtain feedback from them concerning their experience with remote/online teaching. Six out of seven BE teachers responded to our online questionnaire. It was anonymous, and the BE teachers were made aware that it would be used only for the research purposes. As we wanted to measure mainly the satisfaction, we used the common 5-point Likert scale. The questionnaire the respondents took consisted of eleven close-ended and four open-ended questions where they could further comment on the previous close-ended question.

The first set of questions aimed to find out which videoconferencing tools and applications were used most, and also why and how satisfied the BE teachers were using them.

The second set of questions focused on the BE teachers' satisfaction with the students' participation and performance in online lessons, and advantages and disadvantages of online teaching.

The last set of questions asked made the respondents compare online and face-to-face teaching, the quality of those two modes, and express their preference for one of those modes. They were also asked whether they would like to teach a blend of online and face-to-face lessons in the future.

\subsection{Teaching Survey Results}

The first set of questions focused on the preferred videoconferencing tool used, online applications and the BE teachers' satisfaction with these tools and applications.

Chart in Figure 1 shows that the majority $(66.7 \%)$ of the BE teachers decided to use ZOOM for their online lessons.

6 odpovědí

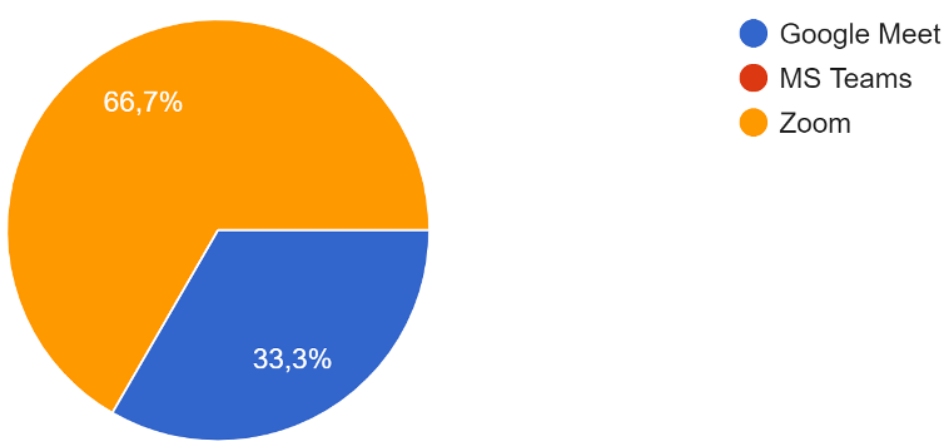

Source: Own

Fig. 1: The videoconferencing tool mostly used for online teaching

Chart in Figure 2 documents that $83.4 \%$ of the BE teachers were satisfied with the selected videoconferencing tool. 


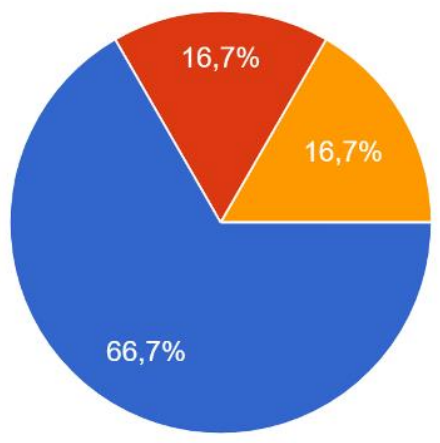

1 - Highly satisfied

2 - Satisfied

3 - Neutral

4 - Dissatisfied

5 - Highly dissatisfied

Source: Own

Fig. 2: The level of satisfaction with the used videoconferencing tool

Chart in Figure 3 illustrates that Wordwall and other applications/tools were the most used ones, followed by Nearpod and LearningApps. The reasons given for using other applications or tools were that they offer a wide range of activites not found elsewhere, they help keep the students engaged and allow practicing various language points in many different ways. Wordwall is very useful for learning new vocabulary and it was mainly used in the compulsory courses for the first-year students. Nearpod is a complex tool allowing teachers to track each student's involvement in real time.

6 odpovědí

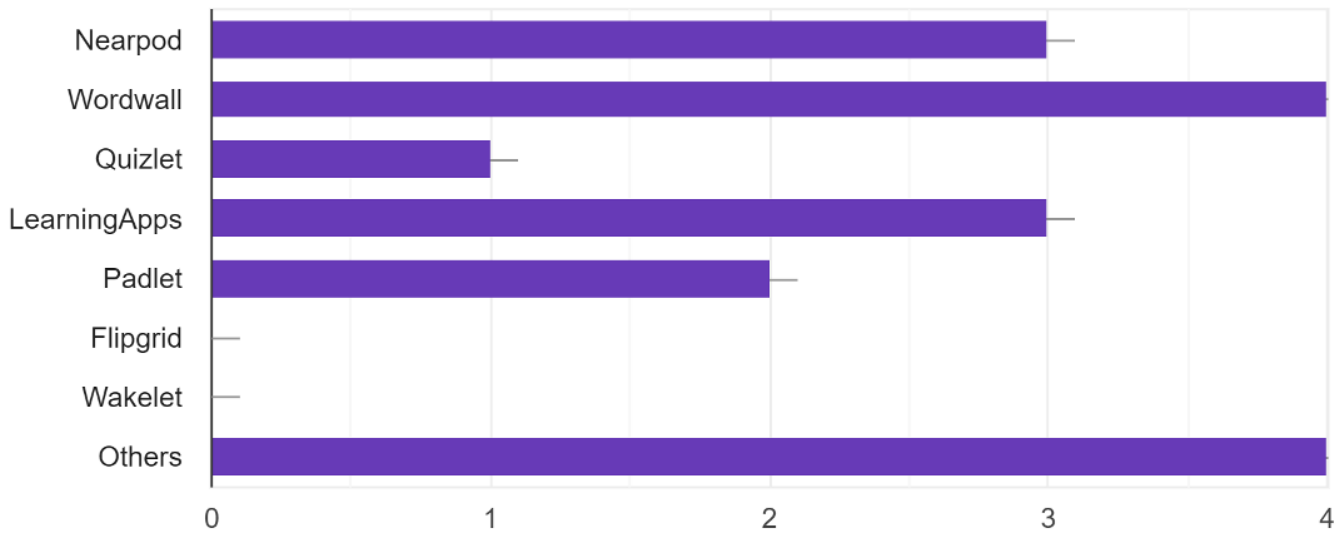

Source: Own

Fig. 3: Tools and/or applications used in online teaching

The second set of questions aimed to find out the BE teachers' satisfaction with the students' participation in online lessons, and the benefits and drawbacks of online teaching.

Chart in Figure 4 shows that $66.7 \%$ of the BE teachers were satisfied with the students' participation and performance in the online English lessons. None of the BE teachers was dissatisfied, which is a positive piece of news. However, in the subsequent open-ended question there were two remarks, namely that some students had lost their motivation and had been tired of being online for so many hours a day, and that students' answers had been drawn from the internet which is not good for their knowledge. Students also got easily distracted, which affected their engagement. 


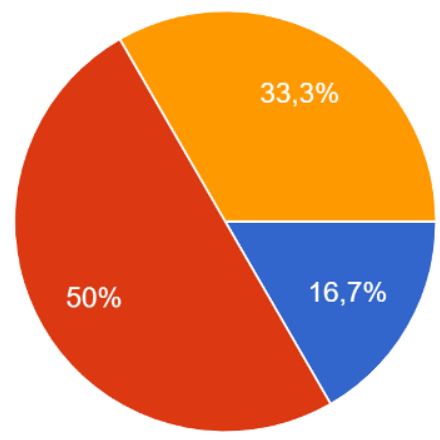

1 - Highly satisfied

2 - Satisfied

3 - Neutral

4 - Dissatisfied

5 - Highly dissatisfied

Source: Own

Fig. 4: The level of satisfaction with the students' participation and performance in online English classes

The advantages of online teaching mentioned by at least half of the respondents are only two, namely that they can use different online resources and can improve their computer skills. Other advantages mentioned in the open-ended question were that even weaker students can improve their English when doing online exercises repeatedly and that shy students can benefit from the online environment because they are not afraid to speak.

As far as the disadvantages of online teaching are concerned, all six BE teachers mentioned fewer interactions with colleagues. This statement was followed by the fact that the preparation of online materials was very time-consuming. There were two comments in the subsequent open-ended question. The first one mentioned missing the students' body language and the second one highlighted the fact that "building a good and quality relationship between the teacher and students and among the students themselves takes more effort in the online environment".

6 odpovědí
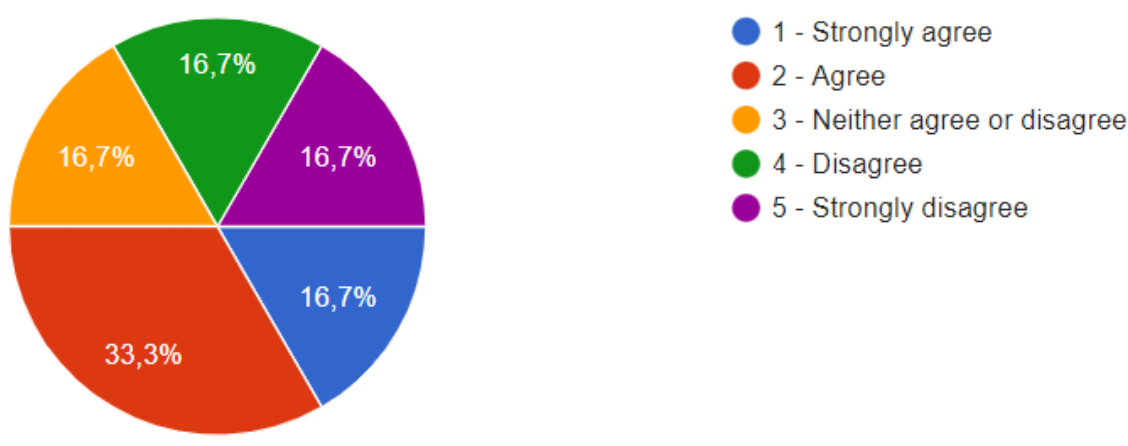

Source: Own

Fig. 5: In the future, I would like to teach a blend of online and face-to-face classes

The last set of questions focused on comparing the quality of online and offline teaching, and the BE teachers' preference for one of these settings. The answers to the question on the quality of online and offline teaching differ significantly. $50 \%$ of respondents disagree with the statement that the quality of online and offline teaching is the same. $33.3 \%$ neither agree nor disagree. This is also evidenced by the result of the subsequent question, in which $50 \%$ of the BE teachers prefer face-to-face teaching and $50 \%$ prefer a blend of online and face-to-face 
lessons. Chart in Figure 5 also shows that $50 \%$ of the BE teachers would like to teach a blend of online and face-to-face lessons in the future.

The online teaching survey has thus confirmed that the BE teachers want to use some elements of online teaching in the future BE courses.

\section{Online Learning Survey}

At the same time, i.e., at the beginning of May 2021, a very similar questionnaire, comprising nineteen questions, was sent to the BE students to obtain feedback concerning their experience with remote/online learning. The students of both compulsory and optional BE courses were polled. 126 students responded to our online questionnaire. All respondents were made aware that the survey was anonymous, however, as it was the end of the semester and the majority of the third-year students had already left, the response rate was only $22.1 \%$. Again, the 5-point Likert scale was used to measure the students' satisfaction with different aspects of remote/online learning. The questionnaire the respondents took consisted of fifteen close-ended and four open-ended questions where they could further comment on the previous close-ended questions and assess the impact of remote education on their knowledge of English. The questions addressed to students were very similar to those in the online teaching survey.

\subsection{Learning Survey Results}

The first set of questions focused on the students' satisfaction with the videoconferencing tools used, the types of online applications, and the students' satisfaction with these tools and applications.

Chart in Figure 6 shows that the majority of the students $(82.6 \%)$ were satisfied with the used videoconferencing tools.

126 odpovědí

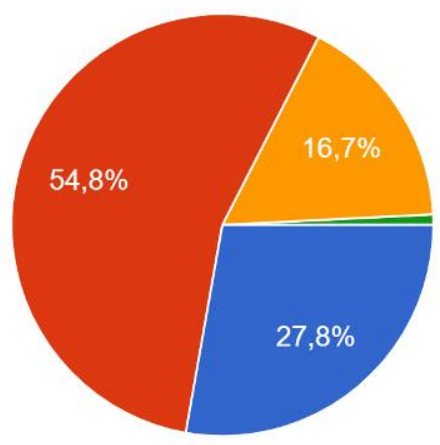

1 - Highly satisfied

2 - Satisfied

3 - Neutral

4 - Dissatisfied

5 - Highly dissatisfied

Source: Own

Fig. 6: Chart 6: The level of satisfaction with the used videoconferencing tool

Chart in Figure 7 illustrates the use of different applications/tools. Quizlet is the most frequently used application, followed by Wordwall and the others. Chart in Figure 8 documents the high level of students'satisfaction (74.6\%) with the used applications/tools. 


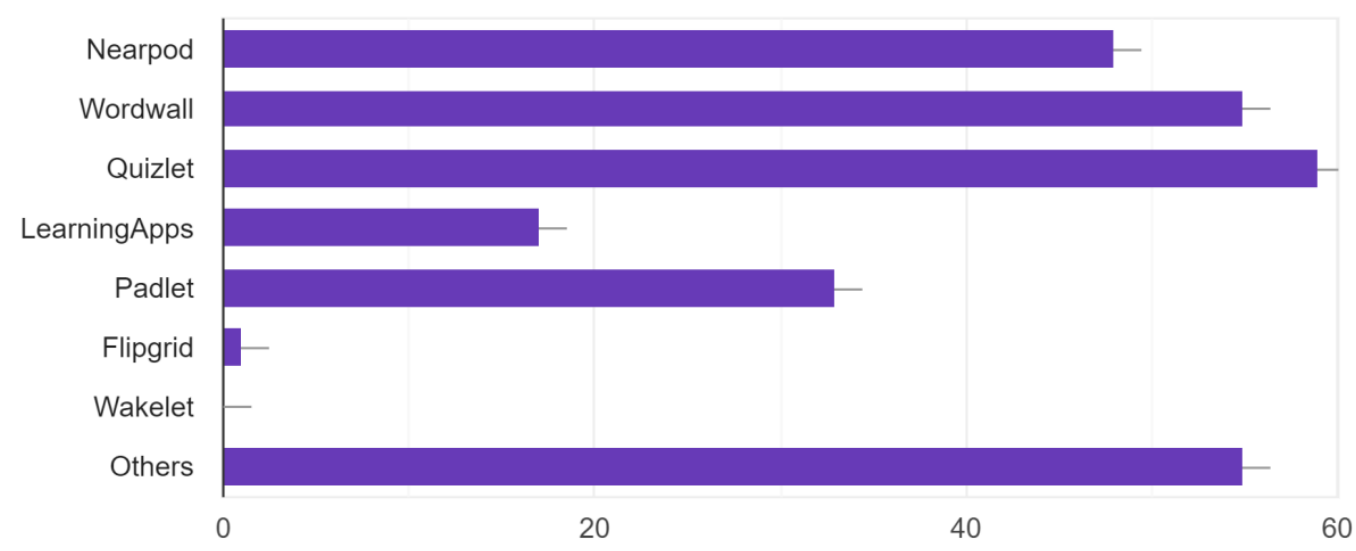

Source: Own

Fig. 7: The tools and/or applications used in your online classes

126 odpovědí

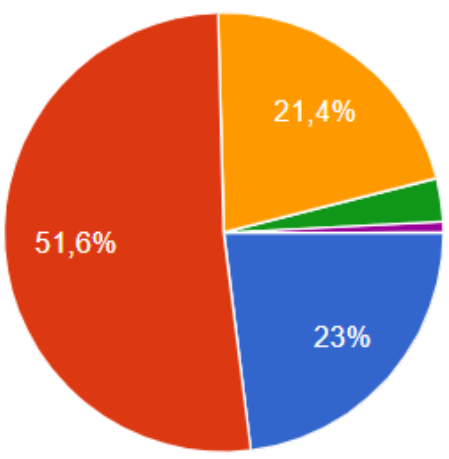

1 - Highly satisfied

2 - Satisfied

3 - Neutral

4 - Dissatisfied

5 - Highly dissatisfied

Source: Own

Fig. 8: The level of satisfaction with the tools and/or applications used in online classes

The second set of questions aimed to find out the level of the students' satisfaction with the quality and organization of online BE lessons, with the teachers' feedback on their work, and the pros and cons of online learning.

It is evident from Chart in Figure 9 that $88.9 \%$ of the BE students highly appreciate the quality and organization of online Business English lessons. Chart in Figure 10 proves that $96.1 \%$ of students also highly value the teachers' feedback on their work.

The advantages of online learning mentioned by at least half of the respondents are as follows: firstly, students do not have to commute, online learning is viewed as flexible and convenient; secondly, there is the possibility of using different online resources that are available also after the lesson; and, last but not least, students can try out different learning methods. Besides, $42.9 \%$ of the respondents stated the fact that online classes are less stressful than face-to-face classes. This was also mentioned several times in the subsequent open-ended question. 
As for the disadvantages of online learning, $58.7 \%$ of the students pointed out that it is difficult for them to focus on the screen for a long time. This is followed by their missing face-to-face interactions with the classmates and the teacher $(57.9 \%)$, and $42.1 \%$ of the students said they felt lonely and isolated. $31 \%$ of the students also mentioned slow or bad internet connection. The answers to the subsequent open-ended question also stressed the fact of not knowing their classmates.

126 odpovědí

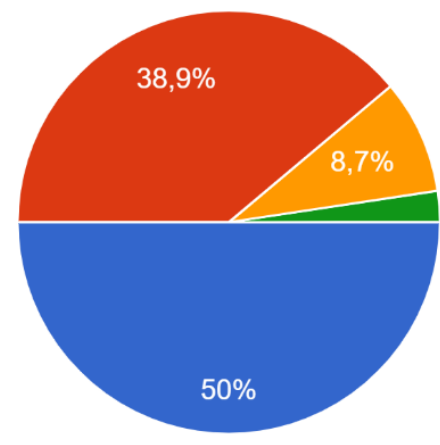

1 - Highly satisfied

2 - Satisfied

3 - Neutral

4 - Dissatisfied

5 - Highly dissatisfied

Source: Own

Fig. 9: The level of satisfaction with the quality and organization of online English classes

126 odpovědí
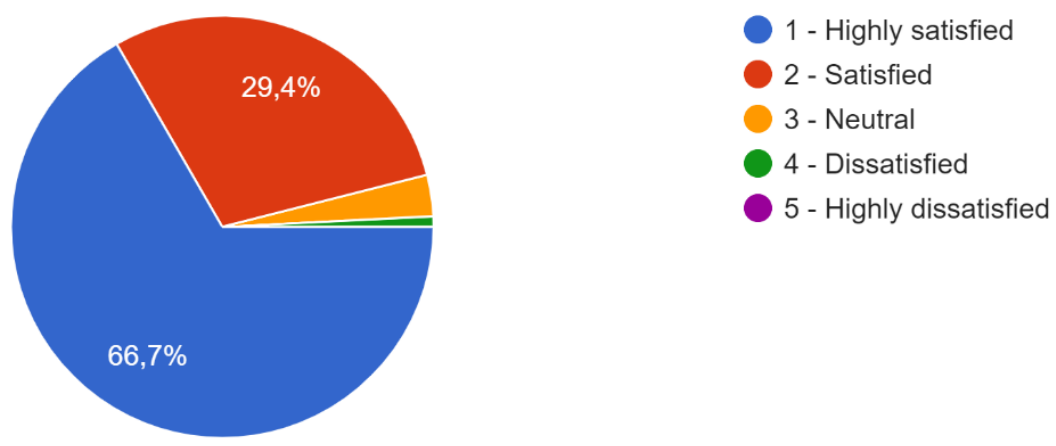

Source: Own

Fig. 10: The level of satisfaction with the teacher's feedback on your work in online English classes

The last set of questions focused on the students' preference for either online or face-to-face classes, the general evaluation of remote/online learning and the mode of learning the students would like to have in the future. As shown in Chart in Figure 11, 52.4\% of the respondents prefer online classes when studying Business English. This is also supported by the result of the subsequent question, in which $61.9 \%$ of the students consider the online classes to be an adequate substitution for the face-to-face classes, see Chart in Figure 12. This is also evidenced by Chart in Figure 13 showing that the same percentage, i.e., $61.9 \%$ of the students would like to have a blend of online and face-to-face classes in the future. 


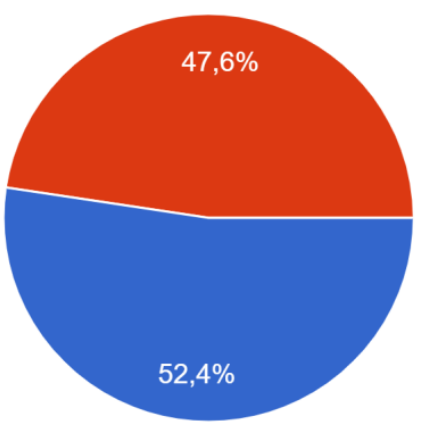

Source: Own

Fig. 11: Preference for either online or face-to-face classes when studying Business English

126 odpovědí

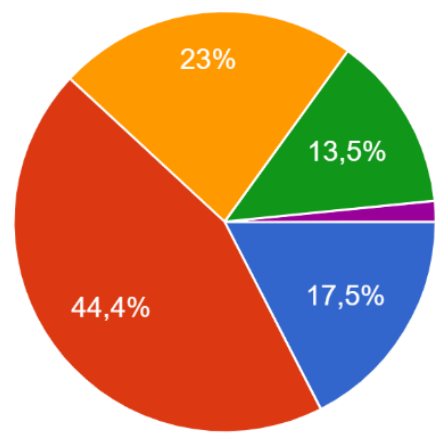

1 - Strongly agree

2 - Agree

3 - Neither agree or disagree

4 - Disagree

5 - Strongly disagree

Source: Own

Fig. 12: The online classes are an adequate substitution for face-to-face classes

126 odpovědí

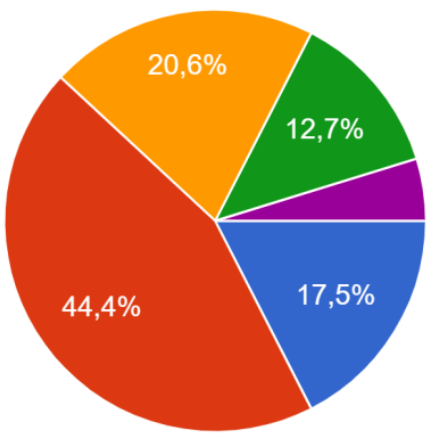

1 - Strongly agree

2 - Agree

3 - Neither agree or disagree

4 - Disagree

5 - Strongly disagree

Source: Own

Fig. 13: I would like to have a blend of online and face-to-face classes in the future

However, Chart in Figure 14 illustrates that the students had mixed feelings when asked whether they had learned more in online classes compared to face-to-face classes. Only $19.9 \%$ of them agree that they learned more in online classes and $52.4 \%$ of the students do not know 
whether online classes benefited them more than face-to-face ones. Thus, this view apparently contrasts with the students' preference for blended learning in the future.

126 odpovědí

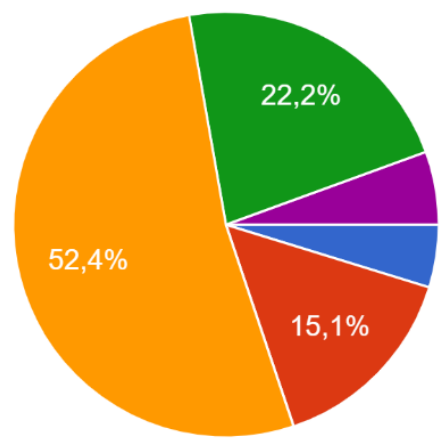

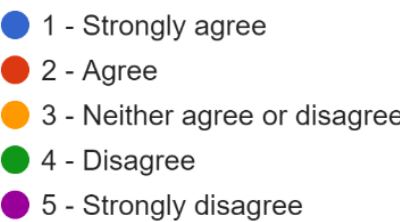

- Strongly disagree

Source: Own

Fig. 14: I have learned more in online classes in comparison to face-to-face classes

Having compared both of the surveys, it is obvious that both the BE teachers and the students agree on the following three facts:

1. Face-to-face classes are a more beneficial and effective way of studying Business English.

2. Online classes are more time consuming.

3. Both the students and teachers miss social interactions in the classroom.

The most surprising fact is that despite the students' hesitation whether they have learned enough in online classes, they still prefer blended learning more than the teachers.

The long experience of remote education has shown the necessity of having one single platform or LMS system and the usefulness of using different online applications and tools. It also made both the teachers and students realize the need to develop also their time management and organizational skills.

\section{Conclusion}

The current situation with the Covid-19 pandemic has made all educational institutions speed up the process of introducing and implementing online elements of teaching and learning. University students have gone through a long period of remote education and the surveys clearly indicate that both the students and teachers have realized the importance of social interactions in face-to-face classes. Yet, at the same time, they appreciate the online experience which allowed them to develop new skills. Therefore, they would like to retain some elements of online education that can help them teach and learn more effectively as well as organize and access the course content better.

The BE teachers and students of economics were no exception. The BE teachers would like to utilize some of the elements from their online teaching and that is why two questionnaire surveys were carried out among the teachers and the students in order to evaluate what worked best and to find out what could be kept from the online form in the future. Our findings confirm Alexeeva \& Buryakova's statement in [6] that

"hybrid, blended learning has a great potential, since it combines the best features of face-to-face learning and the power of information technology." 
The BE teachers at UWB in Pilsen have come to an understanding that it is necessary to keep adapting the Business English courses for the online environment and would like to continue using Google Classroom as a place where all the assignments, links to online exercises and videos, vocabulary and grammar quizzes can be shared and easily accessed both by students and teachers at any time.

\section{Literature}

[1] OFSTED: What's working well in remote education. [online]. 2021. [accessed 2021-0630]. Available from WWW: https://Www.gov.uk/government/publications/whatsworking-well-in-remote-education/whats-working-well-in-remote-education\#what-isremote-education

[2] AMMENWERTH, E.: Envisioning changing role of university teacher in online instructional environments. All Ireland Journal of Higher Education. 2017, Vol. 9, Issue 3. Available from WWW: http://ojs.aishe.org/index.php/aishe-j/article/view/312

[3] RAI, B. S.; RAJESHWARI, M.: Online Language Teaching: Methods and Strategies, Possibilities and Opportunities. International Journal of Management, Technology, and Social Sciences. 2021, Vol. 6, Issue 1, pp. 128-141. [accessed 2021-07-30] DOI: $\underline{10.5281 / \text { zenodo.4606936 }}$

[4] ARMĂSAR, I. P.: Challenges of Online Teaching in the Business Language Class. Bulletin of the Transilvania University of Braşov. Series V: Economic Sciences. DOI: $10.31926 /$ but.es.2020.13.62.2.16

[5] GRUBER, A.: Employing innovative technologies to foster foreign language speaking practice. Academia Letters. January 2021. Article 178. DOI: $\underline{10.20935 / A L 178}$

[6] АЛЕКСЕЕВА, Е. А.; БУРЯКОВА, С. Ю.: Blended foreign language learning with increased online component: hybridization strategies and educational technologies. Научный журнал Современные лингвистические и методико-дидактические исследования. (Scientific Journal Modern Linguistic and Methodically Didactic Researches). 2020, Vol. 48, pp. 75-87. DOI: 10.36622/vstu.2020.26.79.001

[7] UNESCO: Covid-19 and higher education: Today and tomorrow; Impact analysis, policy responses and recommendations. [online]. 2020. [accessed 2021-07-30]. ISBN 978-980-7175-52-4. Available from WWW: https://www.right-toeducation.org/es/node/1317

Mgr. Květoslava Šimková; Mgr. Jitka Ramadanová, PhD. 


\section{VZDĚLÁVÁNÍ ONLINE - ZKUŠENOSTI A VÝZVY}

Tento článek je věnován vybraným aspektům vzdělávání na dálku (online), které by se daly uplatnit i ve výuce prezenční za účelem zkvalitnění a zefektivnění výukového a učebního procesu. Autorky zde seznamují s výsledky dotazníkového šetření, jehož se zúčastnili jak vyučující anglického jazyka Ústavu jazykové př́ípravy Západočeské univerzity v Plzni, tak také studenti ekonomické fakulty téže univerzity. Dotazníkové šetření proběhlo $\mathrm{v}$ letním semestru akademického roku 2020/2021 a účastníci v něm vyjadřovali své názory týkající se vzdělávání na dálku v průběhu posledních dvou semestrů. Autorky posléze shrnuly výsledky dotazníků a na základě jejich analýzy předkládají nabyté poznatky a zkušenosti, které by chtěly využít v kurzech obchodní angličtiny i v budoucnosti.

\section{ONLINE-AUSBILDUNG - ERFAHRUNGEN UND HERAUSFORDERUNGEN}

Dieser Beitrag befasst sich mit ausgewählten Aspekten der (Online-) Fernausbildung, welche man auch im Präsenzunterricht zum Zweck der Anhebung der Qualität und der Effektivität des Lehr- und Lernprozesses einsetzen könnte. Die Autorinnen geben hier die Ergebnisse der Fragebogenuntersuchung bekannt, an der sich die Lehrkräfte am Fremdsprachenzentrum der Westböhmischen Universität Pilsen sowie auch Studenten der ökonomischen Fakultät derselben Universität beteiligt haben. Die Fragebogenuntersuchung verlief im Sommersemester 2020/21 und die Teilnehmer gaben darin ihre Meinung hinsichtlich des Fernunterrichts im Verlauf der letzten beiden Semester zum Ausdruck. Die Autorinnen haben schließlich die Ergebnisse der Fragebögen zusammengefasst und legen nun auf dieser Grundlage interessante Erkenntnisse und Erfahrungen vor, welche sie gern auch in der Zukunft in den Wirtschaftsenglischkursen zum Einsatz bringen wollen.

\section{KSZTAŁCENIE ONLINE - DOŚWIADCZENIA I WYZWANIA}

Niniejszy artykuł poświęcony jest wybranym aspektom zdalnego nauczania (online), które można by zastosować także $\mathrm{w}$ nauczaniu stacjonarnym w celu podniesienia jakości i efektywności procesu dydaktycznego. Autorki przedstawiają wyniki badań ankietowych, w których wzięli udział nauczyciele języka angielskiego z Instytutu Przygotowania Językowego Uniwersytetu Zachodnioczeskiego w Pilźnie oraz studenci Wydziału Ekonomii tejże uczelni. Badania ankietowe przeprowadzono w semestrze letnim roku akademickiego 2020/2021. Ankietowani wyrażali swoje opinie na temat nauki zdalnej prowadzonej w ostatnich dwóch semestrach. Następnie autorki podsumowały wyniki ankiety i na podstawie ich analizy przedstawiły zdobytą wiedzę i doświadczenia, które można by wykorzystać na kursach biznesowego języka angielskiego także w przyszłości. 